\title{
THE OCCURRENCE AND CHARACTER OF STORIES AND STORY-TELLING IN A COMPUTER CONFERENCE 1
}

\author{
Patrick J. Fahy, PhD \\ Professor, Centre for Distance Education \\ Athabasca University \\ $7904-73$ Street \\ Edmonton, AB T6B 1Z6 CANADA \\ 780-469-0549 \\ patf@athabascau.ca
}

13 February 2007

\footnotetext{
${ }^{1}$ Citation: Fahy, P. J. (2007). The occurrence and character of stories and story-telling in a computer conference. Distance Education, 28(1), pp. 45 - 63.
} 


\title{
THE OCCURRENCE AND CHARACTER OF STORIES AND STORY-TELLING IN A COMPUTER CONFERENCE
}

\author{
13 February 2007
}

\begin{abstract}
$\underline{\text { Abstract }}$
Constructivist views of online interaction often refer to the power of stories and the role of story-telling in the sharing and construction of knowledge, and the creation of learning communities. No empirical evidence of the presence or character of stories in online conferences has been systematically reported, however. This study described the occurrence of stories in a CMC (computer-mediated communication) transcript generated by experienced online communicators (graduate students), in relation to some of the expectations of a constructivist view of narrative in online interaction, and in contrast with a historical model for describing face-to-face interaction (Bales, 1950). Findings included the observation that, while stories occurred in about 1 posting in 5 , students used stories markedly more often than the instructor-moderator; stories tended to be descriptive, rather than analytic, advisory, or hortatory; gender was not an issue in story use; and both story and non-story postings were highly group-supportive, providing information and answers to questions, and avoiding negative social interactions (a finding noted previously in moderated, academic conferences).
\end{abstract}




\section{$\underline{\text { Introduction }}$}

Stories invite us to know the world and our place in it. (Witherall, Tran, \& Othus, 1995, p. 40)

Stories do social work. They not only help account for puzzling, unexpected, dramatic, problematic, or exemplary events, but also help confirm, redefine, or challenge social relations. (Tilly, 2006, p. 93)

... human knowledge is encoded as stories about experiences and events. So, when people experience a problem or situation that they do not understand, they should be told stories about similar situations that function as lessons for the current problem. Learners retrieve from related cases advice on how to succeed, pitfalls that may cause failure, what worked or didn't work, and why it didn't work. (Jonassen, 1998, p. 10; emphasis supplied)

As the above shows, constructivists see narratives and story-telling in educational situations as evidence of a community engaged in "learning as conversation" (Jonassen, Davidson, Collins, Campbell, \& Haag, 1995) (Jonassen, 1998). In this view, social interaction occurs within the "call" of the story; the stories themselves convey "more than what is said" (Bruner, 1986, p. 35), providing access to compelling and meaningful problems in an authentic context (Coleman, Perry, \& Schwen, 1997). The combination of social and cognitive engagement is seen as 
potentially richly educational, promoting understanding beyond mere acquisition of facts (Gjedde, 2005; Zalewski, 2006), and bringing users into more “direct and primitive contact with the world" (Merleau-Ponty, 1962, in van Manen, 2003, p. 38).

Story-telling seen in this way is also an expressive social form and an interpersonal vehicle, a means for projecting teaching presence in online groups (Anderson, Rourke, Garrison, \& Archer, 2001), and a resource for forming and sustaining learning communities. According to this outlook, the story form engages those involved with its evocative and imaginative elements; the act of collectively listening to a story promotes social coherence (community), based on the emotions, themes, and vicarious experiences shared by the listeners (Ritchie \& Peters, 2001). The effects can be deep: in case-based learning, engagement with even brief pedagogic narratives can perturb listeners' beliefs (p. 4), sometimes causing reconsideration of fundamental convictions. There is the added benefit that knowledge gained through narrative appears to exhibit greater coherence, probability, and fidelity, resulting in better retention and increased higher-order understanding (Hirokawa, Clauson, \& Dahlberg, 2003, p. 268).

These claims about the occurrence and nature of stories in teaching and learning are unsubstantiated; the present literature contains no reports on the actual presence or character of stories resulting from online learner-learner or learner-moderator CMC (computer-mediated communication) interactions. The purpose of this study was to examine the occurrence and nature of stories and of story-telling in an actual CMC transcript, in order to assess whether and how stories are actually used in the online 
learning process. The intention of the inquiry was to confirm the presence and examine the character of the online interaction in relation to stories, and to determine what story use might suggest about the online communities that generate them.

\section{$\underline{\text { Stories and online communities }}$}

Story-telling is believed to help or hinder the building of interpersonal relationships, individually and at the group level. Stories and story-telling can initiate interaction (stories are often narrated in groups), and sustain it (listening and responding are shared experiences). In terms of network theory, the sharing of stories (or the sharing of elements such as morals and themes) is a form of "interlocked" social behaviour (Weick, 1979), a fundamental form of interrelationship in communities, and an ingredient in the formation and maintenance of all types of communities.

Participants (narrator or audience) share in and reinforce the socio-cultural traditions of the group by their attendance. Such "interlocked" behaviours provide community members with common patterns of social behaviour, reinforcing basic group structures. The story, the act of (re)telling or performing it, and the role of audience member interconnect members and (re)build communities.

With the growth of computer-mediated communications (CMC) in educational contexts, opportunities for the study of story use have been extended. To the degree that stories are forms of social engagement and group reinforcement, an examination of storytelling in CMC should reveal aspects of the social functioning and interpersonal environment of groups focused on learning. Previous work comparing face-to-face with 
online groups has demonstrated that, while there are similarities, there are also some important differences between face-to-face and mediated group interaction, including less social stratification, more flexibility in roles (amounts of previous participation do not seem to restrict subsequent involvement, as they have been shown to do in face-toface group situations) (Bales, 1950; Bales, Strodbeck, Mills, \& Roseborough, 1951), and generally more "democratic" interaction among all group members, regardless of the individual participation levels of those involved (Fahy, 2006).

Theoretical support for analysis of online storytelling in the manner employed here was found in the previous application of historical models to the analysis of face-toface and online interaction (Fahy, 2004, 2006). Bales's Interaction Process Analysis (IPA) model, used in this study, has been used to analyze "systems of human interaction" in small groups (1950, p. 257). As noted above (Fahy, 2004, 2006), the IPA was found to be applicable to both face-to-face and technology-mediated interactions. Use of the IPA model in contemporary contexts is also consistent with its developer's intentions. Bales had earlier expressed his hope that the IPA would add to understanding and explication of "full-scale social systems," through focus of the model on "partial" systems -- small groups (1950, p. 257).

\section{The IPA model}

Bales's IPA model, summarized in Table 1, addresses both the task and the socioemotional agendas of groups. The following summarizes the IPA's key assumptions about groups and interpersonal interaction: 
1. Any group has two major functions (column 1, Table 1): 1) socioemotional viability as a collection of human beings working together; and, 2) the accomplishment of its task, the overt "business" purpose for the group's existence. Both functions must be successfully managed if the group is to be a fully effective entity.

2. In addressing socio-emotional and task functions, groups engage in a range of possible processes (the process column of Table 1). These twelve processes include the actions that may impact a group, positively or negatively affecting its socio-emotional functioning, as it strives to address its task(s).

3. The balance achieved in the group between socio-emotional and task agendas, and positive and negative processes, determines how well the group overcomes the six central problems of group communications identified by Bales (1950; third column, Table 1): integration, tension management, decisions, control, evaluation, and orientation (information management). Its success with these problems, in turn, determines how well a group develops as a community. 
Table 1: System of process categories in the IPA, related socio-emotional group functions, and common communications problems

\begin{tabular}{|c|c|c|}
\hline$\frac{\text { Column } 1}{\text { Function }}$ & $\frac{\text { Column } 2}{\text { Process }}$ & $\begin{array}{l}\text { Column } 3 \\
\text { Paired processes addressing } \\
\text { group's central problems of: }\end{array}$ \\
\hline \multirow{3}{*}{$\begin{array}{l}\text { Social-Emotional Area: } \\
\text { Positive Reaction }\end{array}$} & $\begin{array}{l}\text { 1. Shows solidarity, raises other's } \\
\text { status, gives help, reward }\end{array}$ & $\begin{array}{c}1 \& 12 \\
\text { Problems of integration }\end{array}$ \\
\hline & $\begin{array}{l}\text { 2. Shows tension release, jokes, } \\
\text { laughs, shows satisfaction }\end{array}$ & $\begin{array}{c}2 \& 11 \\
\text { Tension-management }\end{array}$ \\
\hline & $\begin{array}{l}\text { 3. Agrees, shows passive } \\
\text { acceptance, understands, concurs, } \\
\text { complies }\end{array}$ & $\begin{array}{c}3 \& 10 \\
\text { Decision }\end{array}$ \\
\hline \multirow{3}{*}{$\begin{array}{l}\text { Task Area: } \\
\text { Attempted Answers }\end{array}$} & $\begin{array}{l}\text { 4. Gives suggestion, direction, } \\
\text { implying autonomy for other }\end{array}$ & $\begin{array}{c}4 \& 9 \\
\text { Control }\end{array}$ \\
\hline & $\begin{array}{l}\text { 5. Gives opinion, evaluation, } \\
\text { analysis, expresses feeling, wish }\end{array}$ & $\begin{array}{l}5 \& 8 \\
\text { Evaluation }\end{array}$ \\
\hline & $\begin{array}{l}\text { 6. Gives orientation, information, } \\
\text { repeats, clarifies, confirms }\end{array}$ & $\begin{array}{c}6 \& 7 \\
\text { Orientation }\end{array}$ \\
\hline \multirow{3}{*}{$\begin{array}{l}\text { Task Area: } \\
\text { Questions }\end{array}$} & $\begin{array}{l}\text { 7. Asks for orientation, } \\
\text { information repetition, } \\
\text { confirmation }\end{array}$ & $\begin{array}{c}7 \& 6 \\
\text { Orientation }\end{array}$ \\
\hline & $\begin{array}{l}\text { 8. Asks for opinion, evaluation, } \\
\text { analysis, expression of feeling }\end{array}$ & $\begin{array}{c}\quad 8 \& 5 \\
\text { Evaluation }\end{array}$ \\
\hline & $\begin{array}{l}\text { 9. Asks for suggestion, direction, } \\
\text { possible action }\end{array}$ & $\begin{array}{l}9 \& 4 \\
\text { Control }\end{array}$ \\
\hline \multirow{3}{*}{$\begin{array}{l}\text { Social-Emotional Area: } \\
\text { Negative Reactions }\end{array}$} & $\begin{array}{l}\text { 10. Disagrees, shows passive } \\
\text { rejection, formality, withholds help }\end{array}$ & $\begin{array}{c}10 \& 3 \\
\text { Decision }\end{array}$ \\
\hline & $\begin{array}{l}\text { 11. Shows tension, asks for help, } \\
\text { withdraws out of field }\end{array}$ & $\begin{array}{c}11 \& 2 \\
\text { Tension-management }\end{array}$ \\
\hline & $\begin{array}{l}\text { 12. Shows antagonism. Deflates } \\
\text { other's status, defends/asserts self }\end{array}$ & $\begin{array}{c}12 \& 1 \\
\text { Integration }\end{array}$ \\
\hline
\end{tabular}

From Bales (1950, p. 258).

\section{Identifying and classifying stories}

Interaction, in the form of conversational dialogue, has been linked to group

learning by Jonassen (1998) and others (Kanuka \& Anderson, 1998; Kanuka, 2002;

Gunawardena, 1999; Gunawardena, Lowe, \& Anderson, 1997; Garrison, 2000). Beder

(1996) maintains that "groups, not individuals, are the object of education," and that

education must centrally involve participants (p. 74). In this view, stories form an 
important part of interpersonal dialogue, concretely grounding social processes in accounts of direct experience, and, by the social interaction inherent in the story-sharing process, countering the erosion of social bonds due to distance, lack of face-to-face interaction opportunities, or the perceived impersonality of ubiquitous modern media (Ettling, 2001; Moore, 1991).

To identify and analyze stories, in this study Jonassen (1998) and his colleagues' concepts of authentic problem-identification, and problem-solving in context, were adapted and applied. Constructivists hold that, where knowledge acquisition cannot rely on "neatly linear" processes, situated learning, with learner-learner interaction, is preferable. The model sees learning enhanced by context and by the "social, dialogical process" in which "communities ... socially negotiate the meaning of phenomena," (Jonassen, et al., 1995, p. 3).

Jonassen's (1998) published views on situated learning, quoted at the beginning of this paper, provided the criteria used to identify stories and storytellers in this study, and the theoretical focus of the inquiry. According to this rationale, stories are educational when they:

1. preserve context, by focusing on direct, first-person experience;

2. engage the group, as shown by group response(s); and,

3. have the intent of promoting learning (by the presence within them of didactic content and intent).

Based on the above, in this study stories were defined operationally as exhibiting: 
- Immediacy: first-person perspective indicates the story is based upon direct experience with or direct observation of the ideas or situations described.

- Engagement: a response from at least one other member of the community demonstrates at least minimal engagement of the story-teller with the discourse community (Jonassen, 1998, p. 10); the initiation-response pattern also constitutes a double interact (Weick, 1979), indicating the story was considered to be socially "assessable" (Curtis \& Lawson, 2001).

- Didactic purpose: The presence of at least one of the following, indicating the storyteller's intention to impart insights and understanding (educate), and not merely to entertain, or engage in social "phatic communion" ("The language of conversation," 2005), or in "unproductive social interaction" (Curtis \& Lawson, 2001):

(1) advice on how to succeed;

(2) description of pitfalls to be avoided; or, (3) analysis of strategies that worked or didn't work, and comments about why.

The presence of the above, in addition to constituting a didactic purpose for the interaction triggered by the story (p. 6), may be seen as evidence of higher-order thinking - analysis, synthesis/interpretation, evaluation, and metacognition, in relation to the story's ideas or experiences, transformed by cognitive and artistic effort into an engaging narrative (Bloom, Engelhart, Furst, Hill, \& Krathwohl, 1956; Jonassen, 1998, p. 4; Anderson, Krathwohl, Airasian, Cruikshank, Mayer, Pintrich, et al., 2001). 


\section{The study}

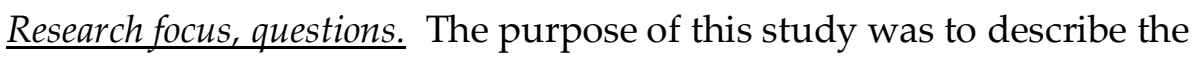
occurrence and character of storytelling in a computer conference, as reflected by analysis of actual stories encountered in a CMC transcript, and from this analysis to describe aspects of the community within whose conversations the stories arose. The following questions were posed to guide the analysis:

1. What was the frequency of stories (Table 2)?

2. What were the characteristics of the stories observed, in relation to the criteria and didactic purposes predicted by constructivists (Jonassen, 1998) (Table 3)?

3. What small-group functions and processes were evident in postings containing stories that met the criteria for selection described above, reflecting on the nature of the online community from which the transcript was derived (Bales, 1950) (Table 4)?

The transcript. The text transcript of a 13-week online graduate course, offered at a distance education university in Canada, was chosen for analysis. Of the 13 weeks of the course, the first week was devoted to introductions, while the remaining 12 weeks addressed course content. The transcript consisted of approximately 75,000 words, in 534 postings (430 postings, $80.5 \%$, made by students; $104,19.5 \%$, by the course instructor). Twenty-six students participated in the online conference as an assignment in the course, worth $10 \%$ of the final grade. The discussion was moderated by the 
instructor, who initially posted general "discussion-starter" questions or observations designed to engage students and provoke a response (see Attachment 2). The instructor also monitored and participated in the resulting interaction. Full marks for conference participation required students to post substantive comments a total of 14 times over the 13 weeks of the course.

The CMC system used was proprietary to the university, but was typical of such systems in being text-only, in presenting messages with the number and titles of messages in the same thread (preserving interrelationships), and showing the identities of respondents and the date and time of each posting.

Coding. Coding was conducted on the course transcript using a modified coderecode protocol. Recognizing that coding reliability is often problematic in transcript research (Fahy, Crawford, \& Ally, 2001; Rourke, Anderson, Garrison, \& Archer, 2001; Garrison, Cleveland-Innes, Koole, \& Kappelman, 2005), a “trial” coding event was conducted to test the coding system, followed by two "production" codings, conducted approximately six months apart, to identify and classify stories found in the transcript. The author conducted all codings.

Multiple codes were assigned to posts if they clearly contained the presence of elements of more than one code. The need for multiple codings was rare, as shown below. Between the first (trial) coding and the first "production" coding (coding event 1), the coefficient of reliability (CR), the percentage agreement between the two codings (Holsti, 1969), was .75; between the two production coding events (coding event 1 and coding event 2), the CR was .85 . 
Story selection criteria. To be included, postings were required to:

1. describe a direct experience, in the first-person;

2. contain content describing what worked, or didn't work (description), why it worked, didn't work (analysis), or Advice). (Examples of each of these from the transcript are shown in Attachment 1);

3. receive at least one response, consistent with the criterion from network theory that a double interact is the basic unit of face-to-face or mediated social discourse (Weick, 1979, p. 35).

Application of the above criteria to the transcript resulted in the selection of 303 of the 534 total postings (57\%) for inclusion in the study. The nature of postings that received no responses was not explored in this study, and is unknown. Inclusion of these in the analysis was deemed problematic because so many reasons for the posting to be apparently ignored were possible (i.e., it was posted after the conference closed and was therefore largely unread by the group, or it contained material seen as tangential, irrelevant, or unproductive for some reason. The nature of postings that do not receive replies - in this study, $43 \%$ of the total - and how these affect the "exchange relations" (Cook, 1982) in the online community, clearly warrant further study, but do not form part of this inquiry.

\section{Findings}

Frequency of stories. Seventy-five stories were identified in 67 of the 303 postings analyzed (22\%), including those authored by the instructor, an overall ratio of 
approximately one story in every 4.5 postings. Stories occurred in the seven units of the course as shown in Table 2.

Table 2: Occurrences of narratives in unit conferences (including the instructor)

\begin{tabular}{|l|c|c|c|c|}
\hline \multicolumn{1}{|c|}{ Unit \# } & $\begin{array}{c}\text { \# of postings } \\
\text { containing stories }\end{array}$ & $\begin{array}{c}\text { Total } \\
\text { stories }\end{array}$ & $\begin{array}{c}\text { Total } \\
\text { postings }\end{array}$ & $\begin{array}{c}\text { \% postings containing } \\
\text { stories }\end{array}$ \\
\hline Unit 1 (2 weeks) & 17 & 20 & 147 & $11.6 \%$ \\
\hline Unit 2 (2 weeks) & 4 & 4 & 61 & 6.6 \\
\hline Unit 3 (1 week) & 9 & 10 & 67 & 13.4 \\
\hline Unit 4 (1 week) & 8 & 9 & 59 & 13.6 \\
\hline Unit 5 (2 weeks) & 9 & 10 & 72 & 12.5 \\
\hline Unit 6 (2 weeks) & 11 & 11 & 57 & 17.5 \\
\hline Unit 7 (2 weeks) & 9 & 11 & 71 & 12.7 \\
\hline Total & $\mathbf{6 7}$ & $\mathbf{7 5}$ & $\mathbf{5 3 4}$ & $\mathbf{1 2 . 6}$ \\
\hline
\end{tabular}

Table 2 shows that the occurrence of stories declined slightly over the term of the course: $57 \%$ of the stories appeared in the first half, and $43 \%$ in the second half. Possible explanations for this trend are offered below. Multiple stories in a single posting were rare: while more than one narrative occurred in a single posting in five of the seven units, no posting contained more than two stories.

The instructor told fewer stories: of 104 instructor postings, only four contained narratives. Of these:

- The first story did not occur until Unit 4; the remaining three followed in Unit 5 (1 story), and in Unit 7 (2 stories).

- The types of the instructor's stories were: advice (1 story), why? (1), and what worked? (2). 
- Engagement with the instructor's stories by students was minimal: only one student replied to each of the four posts containing them.

Characteristics of stories. There were patterns in the types of stories told by students, as shown in Table 3.

Table 3: Narrative types (per Jonassen, 1998), by unit, students' posts only

\begin{tabular}{|l|c|c|c|c|}
\hline \multicolumn{1}{|c|}{ Unit } & $\begin{array}{c}\text { Type 1-What } \\
\text { worked/didn't work? }\end{array}$ & $\begin{array}{c}\text { Type 2 } \\
\text { Why? }\end{array}$ & $\begin{array}{c}\text { Type 3- } \\
\text { Advice }\end{array}$ & Total \\
\hline Unit 1 (2 weeks) & $12 / 29 \%$ & $5 / 45 \%$ & $3 / 16 \%$ & $20 / 28 \%$ \\
\hline Unit 2 (2 weeks) & $2 / 5$ & $0 / 0$ & $2 / 11$ & $4 / 6$ \\
\hline Unit 3 (1 week) & $5 / 12$ & $4 / 36$ & $1 / 5$ & $10 / 14$ \\
\hline Unit 4 (1 week) & $4 / 10$ & $1 / 9$ & $3 / 16$ & $8 / 11$ \\
\hline Unit 5 (2 weeks) & $5 / 12$ & $0 / 0$ & $4 / 21$ & $9 / 13$ \\
\hline Unit 6 (2 weeks) & $6 / 15$ & $1 / 9$ & $4 / 21$ & $11 / 16$ \\
\hline Unit 7 (2 weeks) & $7 / 17$ & $0 / 0$ & $2 / 11$ & $9 / 13$ \\
\hline Total (12 weeks) & $\mathbf{4 1 ~ ( 5 8 \% )}$ & $\mathbf{1 1 ( 1 6 \% )}$ & $\mathbf{1 9 ( 2 7 \% )}$ & $\mathbf{7 1}$ \\
\hline $\begin{array}{l}\text { Avg. responses received } \\
\text { from others }\end{array}$ & $\mathbf{1 . 2 9}$ & $\mathbf{1 . 3 6}$ & $\mathbf{1 . 4 7}$ & $\mathbf{1 . 3 5}$ \\
\hline S.D. & $\mathbf{. 5 5 9}$ & $\mathbf{. 5 0 5}$ & $\mathbf{. 9 6 4}$ & $\mathbf{. 6 7 8}$ \\
\hline Men (n=8) & $\mathbf{1 3 / 3 2 \%}$ & $\mathbf{5 / 4 5 \%}$ & $\mathbf{5 / 2 6 \%}$ & $\mathbf{2 3 / 3 2 \%}$ \\
\hline Women (n=17) & $\mathbf{2 8 / 6 8}$ & $\mathbf{6 / 5 5}$ & $\mathbf{1 4 / 7 4}$ & $\mathbf{4 8} / \mathbf{6 8}$ \\
\hline
\end{tabular}

The patterns noted in Table 3:

- Most student stories (58\%) were type 1, describing (but not analyzing) a situation or an example (What worked/didn't work).

- $\quad$ Students engaged least (16\%) in type 2 analysis (Why?-type stories).

- The average number of responses received from other conference participants to the various types of postings, while not statistically significant, was suggestive: the number of responses made to postings that contained explanations (Type 2 - Why?), and those that contained Advice 
(Type 3), were higher than the average number of responses made to simple descriptions (Type 1 - What worked/didn't work). In this transcript, narratives that lacked a didactic purpose (Type 1) produced less engagement (indicated by fewer responses from others).

Gender. Gender has elsewhere been identified as affecting online behaviour (Herring, 1996; Yates, 1997; Fahy, et al., 2001; Fahy, 2002), but was not found to be a significant factor here. This fact is somewhat obscured in Table 3, where the higher number of women in the group accounts for the greater number of stories by them. When women and men were compared proportionally:

- $\quad$ Use of stories by men and women was similar: women averaged .165 stories per post $($ S.D. $=.096)$, while men averaged $.188($ S.D. $=.149)(F=.204, p=.656)$.

- The occurrence of the three story types was very similar (for gender differences in Table $\left.3, \chi^{2}=1.33, p=.719\right)$.

The above data suggest that "presence," measured by amount of participation in the online conference, was not associated with the story types used by participants (Garrison, Anderson, \& Archer, 2001; Rourke, Anderson, Garrison, \& Archer, 1999), nor was it a function of individual levels of online conference participation: overall, the highest-contributing half of the study group $(n=12)$ did not differ from the lowest contributing $(n=13)$, in terms of the mean number of stories occurring in their postings (.188 vs. .157, respectively).

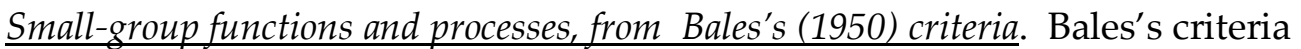
were applied to classify the postings that received at least one response ( $n=303)$, 
including those that contained stories $(n=75)$, in order to determine the group functions, processes, and problems that were addressed, for both story- and non-story-containing postings. This analysis applied Bales's precept that small groups comprise "microscopic social systems"' (Bales, 1950, p. 257), whose workings are capable of illuminating those of larger and more complex communities. As shown in Table 4, postings with and without stories were similar, with specific categories predominating in both.

Table 4: Expected and actual frequencies of Bales's categories

\begin{tabular}{|c|c|c|c|c|c|c|}
\hline \multirow[t]{2}{*}{ Bales's Categories } & \multicolumn{2}{|c|}{$\begin{array}{l}\text { Instructor } \\
(\mathrm{n}=1)\end{array}$} & \multicolumn{2}{|c|}{$\begin{array}{l}\text { Students } \\
(\mathrm{n}=25)\end{array}$} & \multicolumn{2}{|c|}{$\begin{array}{l}\text { Occurrence by Type } \\
(n=26)\end{array}$} \\
\hline & $\begin{array}{c}\text { Actual } \\
\#\end{array}$ & $\begin{array}{c}\text { Expected } \\
\#\end{array}$ & $\begin{array}{c}\text { Actual } \\
\#\end{array}$ & $\begin{array}{c}\text { Expected } \\
\#\end{array}$ & $\begin{array}{l}\text { Story } \\
\# / \%\end{array}$ & $\begin{array}{c}\text { No Story } \\
\# / \%\end{array}$ \\
\hline 1. Shows solidarity & 1 & 3.6 & 12 & 9.4 & $13 / 5.7 \%$ & $4 / 5.3 \%$ \\
\hline 2. Shows tension release & 0 & 0.8 & 3 & 2.2 & $3 / 1.3$ & $1 / 1.3$ \\
\hline 3. Agrees & 4 & 5.1 & 14 & 12.9 & $18 / 7.9$ & $10 / 13.3$ \\
\hline 4. Gives suggestion & 6 & 2.2 & 2 & 5.8 & $8 / 3.5$ & $2 / 2.7$ \\
\hline 5. Gives opinion & 20 & 34.8 & 104 & 89.2 & $124 / 54.4$ & $44 / 58.7$ \\
\hline 6. Gives orientation & 7 & 7.0 & 18 & 18.0 & $25 / 11.0$ & $13 / 17.3$ \\
\hline 7. Asks for orientation & 3 & 1.4 & 2 & 3.6 & $5 / 2.2$ & $0 / 0$ \\
\hline 8. Asks for opinion & 23 & 7.0 & 2 & 18.0 & $25 / 11.0$ & $0 / 0$ \\
\hline 9. Asks for suggestions & 0 & -- & 0 & -- & $0 / 0$ & $0 / 0$ \\
\hline 10. Disagrees & 0 & 2.0 & 7 & 5.0 & $7 / 3.1$ & $1 / 1.3$ \\
\hline 11. Shows tension & 0 & -- & 0 & -- & $0 / 0$ & $0 / 0$ \\
\hline 12. Shows antagonism & 0 & -- & 0 & - & $0 / 0$ & $0 / 0$ \\
\hline Total & 64 & & 164 & & 228 & 75 \\
\hline
\end{tabular}

$-\mathrm{X}^{2}=102.24, \mathrm{df}=8, p<.001$

- Bold/offset figures indicate $50 \%$ or more variance between actual and expected values.

Striking in the above, in terms of the apparent social organization and environment of this small group, and addressing the nature of the socioemotional climate of the online community, were these findings:

1. The almost complete absence of negative socio-emotional interaction (categories 10 to 12 ); 
2. The preponderance of certain category types: $77 \%$ of the postings fell into one of three categories, and over half fell into a single category: Category 5 Gives opinion (55\%), Category 6 - Gives orientation (13\%), and Category 3 Agrees (9\%).

3. The close similarity in the proportion of Bales's types in both story and nonstory posts.

4. These observations concerned differences between the story-telling behaviour and story use of students and the instructor-moderator; the instructor was found to be:

a. Considerably less likely to give opinions (Category 5).

b. Considerably more likely to ask for opinions (Category 8).

c. Somewhat less likely than the students to show solidarity (Category 1), agreement (Category 3), and disagreement (Category 10).

d. Somewhat more likely to give suggestions (Category 4), and ask for orientation (Category 7).

5. Overall, the postings with and without stories, both by students and the instructor, did not differ statistically in relation to the presence of Bales's categories: for both, the most frequent types of posts were, in order of frequency,

a. Attempted answers (Bales's Categories 4 to $6 ; 69 \%$ );

b. Positive socio-emotional reactions (Categories 1 to 3; 15\%);

c. Questions (Categories 7 to 9; 13\%); and 
d. Negative socio-emotional reactions (Categories 10 to $12 ; 3 \%$ ).

\section{Conclusions and implications}

This study explored how constructivist assertions and criteria about the central importance of group interaction to meaningful learning (Jonassen, et al., 1995) were reflected in the actual presence of stories and story-telling in a small online group. The purpose was to describe and analyze empirically the occurrence and characteristics of stories in actual course-based CMC interactions, in relation to views found in the constructivist literature on stories and story-telling in learning. The three objectives were: 1) to determine how often stories occurred; 2) to classify the types of stories according to constructivist criteria (Jonassen, 1998); and, 3) to use the findings to infer interpersonal functions and processes present in the community that produced the stories (Bales, 1950).

Overall, the ratio of stories to posts was 1:26 (a $4 \%$ occurrence) for the instructor, and less than 1:5 (a 22\% occurrence) among students. The relatively modest use of narratives by the instructor might be seen by some as contrary to what is expected of the leader and model of the online community (Bruner, 1986). However, and importantly in relation to the issue of moderator presence here, the lack of story-telling did not indicate any want of teaching presence: by other standards, the instructor-moderator was highly involved in the online interaction, contributing frequently (he made over one-fifth of the posts), and interacting with all members of the group at least once. Contact with all members of the group gave the instructor a network density figure of 1.0, which, 
according to Ridley and Avery (1979), is the most reliable measure of community involvement. Similarly, in Weick's (1979) terms, the achievement of double interacts with all members of the group is a measure of the instructor's success in engaging with the online community.

The fact that the occurrence of stories declined slightly over the term of the course (57\% occurred in the first half) might be associated with increasing socioemotional comfort within the group: Molinari (2004) found that, with greater interpersonal familiarity, group members tended to focus more on problem-solving, decreasing socializing and relationship-building. If storytelling is related to relationship-building, that result might be expected. On the other hand, $90 \%$ of the stories containing analysis (type 2) occurred in the first half of the course, $45 \%$ of these were found in the first 2 weeks, and advice-focused stories were found about equally in both halves, suggesting that interpersonal comfort was relatively high from the beginning (see Table 3). The relation of measures of interpersonal "group comfort" to online activity requires further investigation.

Story-telling in the group was found to be primarily descriptive (descriptions of occurrences or experiences constituted $58 \%$ of stories), with occurrences about evenly distributed throughout all course units (Table 3). Advice giving stories (27\% of the total) and those featuring analysis (discussing why something had happened; $16 \%$ ) followed in frequency, with distribution patterns as shown above (Table 3). Advice was almost exclusively reserved for the first half of the course: $90 \%$ of postings containing advice occurred in the first half of the term. 
Although some previous research in online interaction had noted gender differences, men and women did not differ here in their story-telling behaviour. This may constitute another indication of the character of interpersonal functioning in this community: women have been reported to be more attuned to and more often adversely affected by online group interaction patterns, effects, and dynamics (Yates, 1997; Herring, 1992, 1996; Rodino, 1997), but as they were not so affected here it may have been because the group was consistently harmonious. The effect of the unequal gender ratio in the group was not investigated; some researchers have reported negative effects when ratios are unequal (Bernard, Abrami, Lou, Borokhovski, Wade, Wozney, et al., 2004).

Overall, the story types found in the interaction, and the distribution of postings in relation to Bales's IPA (1950), indicated an inquiring, positive interpersonal group environment, and presided over by an instructor who more often solicited the views of others than he professed his own. Over half of the group's postings offered opinions (55\%) or gave information (13\%), and another $9 \%$ gave support (agreement); there was a complete absence of tension- or antagonism-showing; and the instructor gave fewer of his own opinions, while asking for more of others', than would have been expected statistically. In sum, the group spent over $70 \%$ of its conference time seeking answers, and $16 \%$ in providing positive support (consisting of showing solidarity, agreement, or tension-release strategies). This group appeared to confirm Jonassen's (1998, p. 10) assertion: 
Learning most naturally occurs not in isolation but by teams of people working together to solve problems.... Problems are solved when a group works toward developing a common conception of the problem, so their energies can be focused on solving it. (Jonassen, 1998, p. 10)

Other interpretations of these findings, constituting other implications for the research questions and the underlying constructivist rationale, are possible, and are offered for consideration in the context of this study, and as worthy of further investigation:

- Stories appeared in this group to be less important than some theorists have claimed. The use of stories by other populations should be explored.

- Use of the presence of stories in conferences to assess the cognitive or interpersonal merit of group interaction may be questionable, simply because stories were found to be relatively rare. The enthusiasm of constructivists like Jonassen (1998, p. 10) for the efficacy of "stories ... that function as lessons" is not supported by the findings of this study.

- Even without an explicit invitation to do so, students spontaneously provided opinions, information, and advice to one another, about equally in postings with and without stories. Two contrasting interpretations of this finding arise: 1) such behavior was in contrast to the behaviour modeled by the instructor (who asked for opinions more than giving his own), and is a sign that students did not imitate what the instructor modeled; or, 2) because the instructor so often asked for opinions and information from students, 
they were merely providing what was asked of them. Study is warranted of the purposes and motives of students as they participate variously in CMC.

- Interpersonal behavior in this group was uniformly without negative socioemotional content: no instances of flaming or rudeness occurred, a finding observed elsewhere in similar moderated academic environments (Fahy, 2002). 


\section{References}

Anderson, L.W., Krathwohl, D.R., Airasian, P. W., Cruikshank, K.A., Mayer, R.E., Pintrich, P. R., Raths, J., \& Wittrock, M. C. (2001). A taxonomy for learning, teaching, and assessing. A revision of Bloom's taxonomy of educational objectives (abridged edition). Toronto: Addison Wesley Longman, Inc.

Anderson, T., Rourke, L., Garrison, D.R. \& Archer, W. (2001). Assessing teaching presence in a computer conferencing context. Journal of Asynchronous Learning Networks, 5(2), pp. $1-17$.

Bales, R. F. (1950). A set of categories for the analysis of small group interaction. American Sociological Review, 15(2), pp. 257 - 263.

Bales, R. F., Strodbeck, F. L., Mills, T. M. \& Roseborough, M. E. (1951). Channels of communication in small groups. American Sociological Review, 16(4), pp. 461 468.

Beder, H. (1996). Popular education: An appropriate strategy for community-based organizations. In P. Sissel, (Ed.), A community-based approach to literacy programs: Taking learners' lives into account. New Directions for Adult and Continuing Education Series, \#70 (pp. 73-81). San Francisco: Jossey-Bass.

Bernard, R., Abrami, P., Lou, Y., Borokhovski, E., Wade, A., Wozney, L., Wallet, P. A., Fiset, M., \& Huang, B. (2004). How does distance education compare to classroom instruction? A meta-analysis of the empirical literature. Review of Educational Research, 74(3), pp. 379 - 439, Fall. 
Bloom, B.S., Engelhart, M.D., Furst, E.J., Hill, W.H. \& Krathwohl, D.R. (1956). Taxonomy of educational objectives: The classification of educational goals. Handbook 1: Cognitive domain. New York: David McKay Co., Inc.

Bruner, J. (1986). Actual minds, possible worlds. Cambridge, Mass: Harvard University Press.

Coleman, S., Perry, J., \& Schwen, T. (1997). Constructivist instructional development: Reflecting on practice from an alternative paradigm. In A. J. Romiszowski (Ed.), Instructional Development Paradigms (pp. 269-282). Englewood Cliffs, New Jersey: Educational Technology Publications.

Cook, K. (1982). Network structures from an exchange perspective. In P. Marsden \& N. Lin (Eds.), Social structure and network analysis (pp. 177 - 199). Beverly Hills: Sage Publications.

Curtis, D. \& Lawson, M. (2001). Exploring collaborative online learning. Journal of Asynchronous Learning Networks, 5(1). Downloaded October 15, 2001, from: www.sloan-c.org/publications/jaln/v5n1/pdf/v5n1_curtis.pdf

Ettling, D. (2001). Leadership for Action: Wedding Adult Education and Social Change. Proceedings of Adult Education Research Conference. Retrieved April 5, 2004 from $\underline{\text { www.edst.educ.ubc.ca/aerc/index.htm }}$

Fahy, P. J., Crawford, G. \& Ally, M. (2001). Patterns of interaction in a computer conference transcript. International Review of Research in Open and Distance Learning, 2(1). Available: http://www.irrodl.org/content/v2.1/fahy.html. 
Fahy, P. J. (2002). Epistolary and expository interaction patterns in a computer conference transcript. Journal of Distance Education, 17(1), pp. 20 - 35.

Fahy, P. J. (2004). Use of the Bales model for analysis of small-group communications in the analysis of interaction in computer-based asynchronous conferences. Paper presented at the IASTED International Conference on Knowledge Sharing and Collaborative Engineering (KSCE 2004), November 22-24, St. Thomas, US Virgin Islands.

Fahy, P. J. (2006). Online and face-to-face group interaction processes compared using Bales' Interaction Process Analysis (IPA). European Journal of Open, Distance, and Elearning. Available: http://www.eurodl.org/materials/contrib/2006/Patrick_J Fahy.htm

Garrison, R. (2000). Theoretical challenges for distance education in the twenty-first century: a shift from structural to transactional issues. International Review of Research in Open and Distance Learning, 1(1). Retrieved September 29, 2000, from http://www.icaap.org/iuicode?149.1.1.2. (IRRODL(1)1, June, 2000).

Garrison, D. R., Anderson, T., \& Archer, W. (2001). Critical thinking, cognitive presence, and computer conferencing in distance education. The American Journal of Distance Education, 15(1), pp. 7-23.

Garrison, D.R., Cleveland-Innes, M., Koole, M., \& Kappelman, J. (2005). Revisiting methodological issues in transcript analysis: Negotiated coding and reliability. Internet and Higher Education, 9(1), pp. $1-8$. 
Gjedde, L. (2005). Designing for learning and narrative multimedia environments. In S. Mishra \& R. C. Sharma (Eds.), Interactive multimedia in education and training (pp. 101 - 111. Hershey, PA: Idea Group Publishing.

Gunawardena, L. (1999). The challenge of designing and evaluating "interaction" in web-bested distance education. Paper presented at WebNet 99, World Conference on the WWW and Internet. ERIC Documents ED 448718.

Gunawardena, C., Lowe, C. \& Anderson, T. (1997). Analysis of a global on-line debate and the development of an interaction analysis model for examining social construction of knowledge in computer conferencing. Journal of Educational Computing Research, 17(4), pp. 395-429.

Herring, S. (1992). Gender and participation in computer-mediated linguistic discourse. Paper presented at the annual meeting of the linguistic society of America, Philadelphia, January 9 - 12. ERIC ED345552.

Herring, S. C. (1996). Two variants of an electronic message schema. In Susan C. Herring (Ed.), Computer-mediated communication. Philadelphia: John Benjamins Publishing Co., pp. 81-106.

Hirokawa, R. Y., Clauson, K. M., \& Dahlberg, J. (2003). Narrative analysis of group communication. In R. Y. Hirokawa, R. S. Cathcart, L. A. Samovar, \& L. D. Henman, Small group communication: Theory and practice, $8^{\text {th }}$ ed. (pp. 267 - 274). Los Angeles: Roxbury Publishing Co.

Holsti, O. (1969). Content analysis for the social sciences and humanities. Don Mills, Ontario: Addison-Wesley. 
Jonassen, D. (1998). Designing constructivist learning environments. In C.M. Reigeluth (Ed.), Instructional Theories and Models (2nd ed., pp. 1-21.) Mahwah, New Jersey: Lawrence Erlbaum.

Jonassen, D., Davidson, M., Collins, M., Campbell, J., \& Haag, B. (1995). Constructivism and computer-mediated communication in distance education. American Journal of Distance Education, 9(2), pp. 7 - 26.

Kanuka, H. (2002). A principled approach to facilitating distance education: The Internet, higher education and higher levels of learning. Journal of distance education, 17(2), pp. $70--86$.

Kanuka, H. \& Anderson, T. (1998). Online social interchange, discord, and knowledge construction. Journal of Distance Education, 13(1), spring, pp. 57 - 74.

Moore, M. G. (1991). Editorial: Distance education theory. The American Journal of Distance Education, 5(3), pp. 1-6.

Molinari, D. L. (2004). The role of social comments in problem-solving groups in an online class. The American Journal of Distance Education, 18(2), pp. 89 --101.

Ridley, C. \& Avery, A. (1979). Social network influence on the dyadic relationship. In Burgess, R. \& Huston, T. (Eds.). Social exchange in developing relationships (pp. 223 - 246). New York: Academic Press.

Ritchie, G. \& Peters, S. (2001). Using narratives in conferences to improve the CMC learning environment. Journal of Computer-Assisted Learning, 17(4), pp. 376 - 385.

Rodino, M. (1997). Breaking out of binaries: Reconceptualizing gender and its relationship to language in computer-mediated communication. Journal of 
Computer-Mediated Communications, 13(3). Available:

http://jcmc.indiana.edu/vol3/issue3/rodino.html.

Rourke, L., Anderson, T., Garrison, R. \& Archer, W. (1999). Assessing social presence in asynchronous text-based computer conferencing. Journal of Distance Education, 14(2), pp. 50-71.

Rourke, L., Anderson, T., Garrison, D. R., \& Archer, W. (2001). Methodological issues in the content analysis of computer conference transcripts. International Journal of Artificial Intelligence in Education, 12, pp. 8-22. Available from: http://aied.inf.ed.ac.uk/members01/archive/vol 12/rourke/full.html.

The language of conversation. (2005). Phatic communion. Downloaded October 18, 2005, from http://english.unitecnology.ac.nz/resources/resources/conversation/part1-C.html Tilly, C. (2006). Why? Princeton: Princeton University Press.

van Manen, M. (1997). Researching lived experience. London, Ontario: The University of Western Ontario.

Weick, K. E. (1979). The social psychology of organizing, $2^{\text {nd }}$ edition. Reading, Mass.: Addison-Wesley Pub. Co.

Witherall, C.S., Tran, H.T., \& Othus, J. (1995). Narrative landscapes and the moral imagination: Taking the story to heart. In H. McEwan, \& K. Egan (Eds.), Narrative in teaching, learning, and research. (pp. 39-49). New York: Teachers College Press. 
Yates, S. J. (1997). Gender, identity and CMC. Journal of Computer-Assisted Learning, 13(4), pp. $281-290$.

Zalewski, D. (2006, April 24). The ecstatic truth. The New Yorker, pp. 124-139. 


\section{ATTACHMENT 1}

Postings are edited to correct obvious errors in spelling and punctuation.

\section{What worked/didn't work}

\section{Example 1.1:}

I agree, the current version of [an LMS system] is not as easy to work with as the old version. I had to use the new version and there were many bugs to deal with. Some problems should never have been there in the first place. For example, an instructor couldn't edit a quiz once the questions were added to the quiz. You had to delete the quiz, create a new quiz with the same name, and then enter the new (edited) questions. I wasted almost a whole day on this one. Most of the bugs have now been fixed by the 3.1.1 Patch. Guess what? We are upgrading again. I think the new version will be version 3.5. There is already a problem. Netscape 6 will not work with the new version....

\section{Example 1.2:}

I remember my father, a former school teacher and principal, coordinating an outdoor education program for [a school district in Alberta, Canada] which included studying evolution and fossils "in DRUMHELLER" and studying biology "at PINELAKE". The students not only interacted but learned other social skills while on the road. They even accommodated those with health and physical impediments. Thus, the classroom was brought to the "real world."

2) Why it did/didn't work

\section{Example 2.1:}


I agree about the jumping on the bandwagon or keeping up with the Jones. Take

Netscape 6. Touted as the new and improved browser that will beat IE5 hands down;

installed it, hated the changes, lost half my ability to function effectively with it so took it off. It may be different and have some other things built in, but there's nothing wrong with 4.75. Sometimes less is more.

Example 2.2: I opted to take a course on Excel and while it was Excel 97 rather 2000, I did learn some good basics from the class which was for one day. However there was another student there who had no computer (at least no spreadsheet knowledge) and the poor guy had a real tough time. What didn't help was the attitude and approach of the instructor towards his lack of knowledge. The instructor's rather ignorant (rude) approach showed me a better way of dealing with learners who are having a tough time. Patience would be part of that formula I'm sure???

\section{3) Advice}

Example 3.3: I think I have an answer for you [name]. It is delayed gratification. Yes I am chuckling a little but I am serious. Living out of the country where electricity and formats for hardware are not compatible (not to mention the outlandish costs) really forces you to think about what you NEED and what you WANT. My husband works for IBM in research and development. He is a techno-junkie. All the toys all the time. For the past 2 1/2 years that has been put on hold and it has been interesting to see that both of us function just fine on the equipment and software we brought with us. No major upgrades on hardware or software. Now when we get home I am sure some 
changes will occur as we both see the need for faster modem access. I think if companies wait, and proceed with caution, then appropriate choices will come about.

Example 3.2: I am on a business trip in a place called Arctic Bay, Nunavut, and it has been made so clear to me how important technology is in the delivery of distance education. Without the technology that makes possible the accessing of the Internet around the world, I would not be able to participate very effectively in this course.... Something that an organization must consider is that the basic infrastructure is in place to service any other add-ons that will provide the organization with the tools to deliver their services/education. 


\section{ATTACHMENT 2}

\section{Computer-Mediated Conference Starters}

\section{Unit Intro:}

Briefly introduce yourself. Tell us about your work background, your career, your experiences in the program so far, and your particular interests in this course. Do you have a background in technology you want to mention? If you like collaborating, and are looking for a partner for a project or an assignment, this might be a good place to mention it. See the Assignments regarding collaborations.

\section{Unit 1:}

1.1 The title of this course might raise some questions: what are advanced technologies? What do you expect when you see the term? What makes a tool a technology? What makes a technology advanced? Is there such a thing as a "nonadvanced" technology?

1.2 Definitions are important, but may be difficult in this area. What is a "technology?" What is a "learning technology"? If there is a published definition you like, give it, and explain why you like it.

1.3 What are some differences between a technology and a gadget?

\section{Unit 2:}

2.1 This unit deals with organizations, and the parts of organizations that technologies, as innovations, usually impact. Give an example (real, if possible) of how an organization might approach an important innovation like technology. How does it decide whether to adopt it or not?

2.2 Have you ever worked in or encountered what Senge would call a true learning organization? Describe some of its characteristics.

2.3 Describe a significant barrier to change in an organization or situation you are familiar with. What caused the barrier? What might reduce or eliminate it?

\section{Unit 3:}


3.1 Based on your experience, what is a major merit or shortcoming of print in your situation or organization?

3.2 Describe how print works or fails in an important way as a training tool within your organization.

3.3 What future do you see for print in your environment? Especially, what changes do you expect to see in its use?

\section{Unit 4:}

4.1 Based on your experience, what is a major merit or shortcoming of audio-based technologies in your organization?

4.2 Describe how audio-based technologies work or fail in an important way within your organization.

4.3 What future do you see for audio-based technologies in your organization?

\section{Unit 5:}

5.1 Based on your experience, what is a major merit or shortcoming of video-based technologies in your organization?

5.2 Describe how video-based technologies succeed or fail in an important way within your organization.

5.3 What future do you see for video-based technologies in your organization?

\section{Unit 6:}

6.1 Computer-based teaching or training (CBT) and communications technologies are, in the minds of some, the tools of our age - it seems that no self-respecting designer fails to include some kind of CBT in any serious funding proposal. What types of CBT are you familiar with, and how well do they work? Describe a major achievement or failing of CBT, in your experience.

6.2 Describe an experience you have personally had with CBT (computer-based training), positive or not, and what it taught you about this medium.

6.3 What do you see as the future of computer-based training (CBT) in your organization, if any? 


\section{Unit 7:}

7.1 At the risk of launching us into a Dilbert-like experience: describe a major achievement or failing of strategic planning in your organization.

7.2 Have you ever been in the role of change agent? Describe the situation, how you handled it, and any important or interesting outcomes.

7.3 Take some point discussed in this unit and comment on it. Did anything strike you as useful, absurd, contrary to your experience, biased, or otherwise interesting in some way?

\section{Unit 8:}

8.1 If you have had experience with development teams, describe the team experience, especially your role. What improvements would have made the team more effective?

8.2 The Study Guide lists some criteria for selecting media (section 8.2). Comment on the list in relation to a specific application or organizational situation familiar to you.

8.3 Apply Bates's ACTIONS model (section 8.3 of the Study Guide) or the SECTIONS model (pp. 65-66 of the textbook) to some development question. How well does the model apply? Which criteria are critical, in your experience? 


\section{$\underline{\text { Biography }}$}

Patrick J. Fahy (patf@athabascau.ca) is a professor in the Centre for Distance Education, Athabasca University, Athabasca, Canada. He teaches in the Master of Distance Education (MDE) program, coordinates the Graduate Diploma in Distance Education (Technology), and organizes the Centre's annual Distance Education Technology Symposium (DETS). He has previously taught in the K12 system, was an instructor and program head of an adult basic education program, and worked for several years in the private sector. He lives in Edmonton with his wife, four sons, and two grandchildren. 